\title{
The Perceptions of Primary School Teachers About Their Application Levels of Measurement and Evaluation Principles*
}

\author{
Sevilay KILMEN* Nükhet ÇIKRIKÇI DEMIRTAŞLI I***
}

\begin{abstract}
The purpose of this research was to determine the primary school teachers' application levels of measurement and evaluation principles according to their own perceptions. 236 primary school teachers who were attending in-service training program in Aksaray in 2006-2007 academic year were involved in this research. The data was collected by a questionnaire with 30 items. Primary schools teachers' level of applying the principles of measurement and evaluation in classroom settings were reported by frequency and percentages. The relationship between the variables-relationship of teachers' frequency level of applications of measurement and evaluation with gender, years of experience in public sector, the department they graduated and the class size of they attended- were determined with Cramer's V coefficient. According to the findings, most of the teachers pay attention to the applications of measurement and evaluation principles. However, they do not use these measurement and evaluation principles in assessment of student achievement in most of time. There is no significant relationship between the variables; primary school teachers' applications of measurement and evaluation, and years of experience in service, faculty they graduated and the class size they attended.
\end{abstract}

Key words: measurement and evaluation, application of measurement and evaluation, teacher's self-perceived assessment skills.

\footnotetext{
* This study is a summary of the thesis submitted to the Ankara University for the degree of Master of Education.

Research Assistant, Ankara University Faculty of Educational Sciences, Department of Measurement and Evaluation, 06590 Cebeci-Ankara, Turkey. Email:kaplansevilay@yahoo.com.

Assoc. Prof. Dr., Ankara University Faculty of Educational Sciences Department of Measurement and Evaluation, 06590 Cebeci-Ankara, Turkey. E-mail:nukhet66@,hotmail.com
} 


\section{SUMMARY}

Assessment is a regular part of the teachers' school routine. The amount of time devoted to assessment varies from teacher to teacher and class to class. Literature reveals that teachers encounter with many problems during their classroom assessments. Moreover, although they don't have enough skills and knowledge regarding various assessment techniques, nevertheless, they apply these techniques for classroom assessments. The main purpose of this study was to investigate perceptions of primary school teachers' frequency levels related to assessment applications are based on measurement and evaluation principles.

Participants of this research comprised of- 236 primary school teachers from several schools in different parts of Turkey. We reached to them at an in-service training program in Aksaray, 2006-2007 academic year. The participants were constituted 106 females and 130 males. The data was collected by a questionnaire which is constructed by the researchers to find out the teachers' application levels about measurement and evaluation principles in four points rating scale questionnaire form which is consisted of 30 items. Teachers were asked to respond to items that addressed their use of assessment techniques. The analyseswas carried out for 236 returned responses by SPSS 15. Primary schools teachers' application levels of the principles of measurement and evaluation in class activities were reported by frequency and percentages. The relationships between the variablesrelationship of teachers' level of use applications of measurement and evaluation with gender, years of experience in service, the faculty they graduated and the number of students in their class were determined with Cramer's V coefficient.

According to the findings, most of the teachers do not often use assessment techniques are based on measurement and evaluation principles. There is no significant differences were found between teachers based on their teaching service years, faculty they graduated and their class size with respect to their use of assessment techniques. Some statistically significant gender differences between teachers existed with respect to the frequency of use of assessment applications (using assessment results when evaluating class improvement, communicating classroom assessment to parents, assessing students trough observations, using concept mapping to assess student learning, using portfolios to assess student progress). Teachers use traditional assessment techniques more frequently than alternative assessment techniques: Considering item types they use, most of the primary school teachers reported that they use multiple choice, short answer, truefalse and matching questions most often than any other type. Half of them do not use assessment plan, concept maps, portfolios, rubrics, attitude scales, performance assessment, self and peer assessment in their classroom assessment applications. Most of them do not prepare assessment instruments to measure higher order thinking skills. 


\title{
Sınıf Öğretmenlerinin Ölçme ve Değerlendirme İlkelerini Uygulama Düzeylerine İlişkin Görüşleri*
}

\author{
Sevilay KILMEN $^{* *} \quad$ Nükhet ÇIKRIKÇI DEMIRTAŞLI ${ }^{* * *}$
}

ÖZ: $\mathrm{Bu}$ çalışmanın amacı, sınıf öğretmenlerinin ölçme ve değerlendirme ilkelerine dayalı sınıf içi öğrenci başarısının izleme ve değerlendirme uygulamalarını gerçekleştirme sıklıklarını, çeşitli değişkenler bakımından, kendi algılarına göre saptamaktır. Bu çalışmanın araştırma grubunu, 2006-2007 eğitim-öğretim yılında, Aksaray ilinde düzenlenen hizmet içi eğitim seminerine katılan 236 sınıf öğretmeni oluşturmaktadır. Araştırma verileri, araştırmacılar tarafından geliştirilen 30 maddelik anketle sağlanmıştır. Öğretmenlerin ölçme ve değerlendirme ilkelerine dayalı uygulamaları gerçekleştirme düzeyleri yüzde ve frekanslarla ifade edilmiş, öğretmenlerin ölçme ve değerlendirme uygulamalarını gerçekleştirme düzeyleri ile cinsiyet, hizmet süresi, mezun oldukları bölüm ve sınıf mevcudu değişkenleri arasındaki ilişki, Cramer V katsayısı ile saptanmıştır. Araştırma sonucunda, sınıf öğretmenlerinin çoğunluğunun ölçme değerlendirme ilkelerine dayalı uygulamaları eğitim öğretim sürecinde, yeterince gerçekleştirmedikleri saptanmıştır. Bazı uygulamalar dışında, sınıf öğretmenlerinin ölçme ve değerlendirme uygulamalarıyla, cinsiyet, hizmet süresi, eğitim fakültesi mezunu olup olmama ve sınıf mevcudu değişkenleri arasında manidar bir ilişki bulunmamıştır.

Anahtar sözcükler: sınıf içi değerlendirme etkinlikleri, öğrenci başarısını değerlendirme, öğretmen yeterlikleri.

\footnotetext{
* Bu çalışma "Sınıf Öğretmenlerinin Ölçme ve Değerlendirme İlkelerinin Önem ve Uygulama Düzeylerine İliş̧kin Görüşleri” isimli tez çalışmasından özetlenerek hazırlanmıştır.

"Araş. Gör., Ankara Üniversitesi Eğitim Bilimleri Fakültesi Eğitimde Psikolojik Hizmetler Bölümü, Ölçme ve Değerlendirme Anabilim Dalı, elektronik posta:kaplansevilay@yahoo.com

Doç. Dr., Ankara Üniversitesi Eğitim Bilimleri Fakültesi Eğitimde Psikolojik Hizmetler Bölümü, Ölçme ve Değerlendirme Anabilim Dalı, elektronik posta: nukhet66@hotmail.com
} 


\section{GiRIS}

Eğitim öğretim ortamında, öğretmen ve öğrenci arasındaki etkileşimin kalitesini büyük ölçüde öğretmenin sahip olduğu yeterlikler belirlemektedir. Okul ve sınıf ortamı ne denli modern araç, gereç ve teknoloji ile donanmış olursa olsun, her şeyden önce öğretmenin mesleki donanımı çok önemlidir. Özellikle temel eğitimde öğrenciyle, ailesinden daha çok zaman geçiren kişi öğretmendir. Böyle düşünüldüğünde, öğretmenlerin, öğrencilerin sadece bilişsel değil psiko-sosyal gelişimlerinde de katkıları büyüktür. Diğer bir ifadeyle, öğretmenin kendisinden beklenen yeterlikleri sergilemesi öğrencinin akademik yaşantılarının yanı sıra, sosyal ve duyuşsal gelişimini doğrudan ya da dolaylı olarak etkileyecektir.

Öğrenci başarısını izleme ve değerlendirme ile ilgili bilgi ve becerilerle donanmış bir öğretmen, öğrenme-öğretme sürecini daha iyi kontrol edebilecektir. $\mathrm{Bu}$ süreçte, eğitimle kazandırılmak istenen öğrenmelerin beklenen düzeyde olup olmadığına karar verebilmek için bazı koşulların yerine getirilmesi gerekir. Önce bu öğrenmelerin, geçerliği ve güvenirliği yeterince yüksek olan ölçme araçlarıyla ölçülmesine ihtiyaç vardır. Bir kişinin belli davranışlarda erişmiş olduğu yetkinlik ve kararlılık nesnel biçimde belirlenmedikçe, bu kişinin ilgili davranışlarda beklenen düzeye erişmiş olup olmadığına karar verilemez (Özçelik, 1981). Bunun yanı sıra öğretmen ve öğrenci değerlendirme-izleme sonuçlarını öğrenme ve öğretme aktivitelerini geliştirmek amacıyla kullanmalıdır. Değerlendirmenin asıl amacı öğrencinin eksiklerini ve üstün olduğu yönleri saptamak, kendisinin de görmesine yardımc1 olmaktır. Bu nedenle öğretmenlerin, öğrencinin çalışmasına/ödevine veya ürününe ilişkin nitel değerlendirmeler yapmalıdır. Öğrenci için değerlendirme sonucunun, bir geçme notundan daha fazla şey ifade edebilmesi için, öğretmenin, öğrencinin başarabildiklerini ve öğrenme eksiklerini tanımlayabilmesi gerekmektedir (Stiggins ve Chappuis, 2005).

Stiggins (2002)'e göre değerlendirmenin öğrenmeye hizmet edebilmesi için başarı hedefleri açıkça ifade edilmelidir. Öğrenme ve öğretme sürecinin en başında, öğrencilere başarı hedefleri ile ilgili bilgiler verilerek bu hedefleri iyice anlamaları sağlanmalıdır. Öğretmenler değerlendirme konusunda yeterli bilgiye sahip olmalıdır. Öğrenciden beklenenler, öğrenci başarısını tam olarak yansıtan değerlendirme etkinliklerine ve puanlama sürecine aktarılmalıdır. Değerlendirme, öğrencinin bir öğrenen olarak kendine güvenmesi ve kendi öğrenmeleri için sorumluluk almasına yardımcı olmak için kullanılmalıdır. Değerlendirme sonuçları yargısal geribildirimden çok, betimleyici geribildirimlere dönüştürülmelidir. Eğitim, sürekli olarak, değerlendirme sonuçlarına göre düzenlenmelidir. Öğrencinin kendini değerlendirmesi sağlanmalıdır. Böylece öğrenci kendi zaman içindeki 
gelişimini izleyebilmeli ve kendi başarısından sorumlu olduğunu hissetmelidir. Öğrencinin başarı düzeyi ve gelişimi ailesiyle paylaşılmalıdır..

Ölçme ve değerlendirme hangi amaçla yapılırsa yapılsın bir takım değerlendirme ilkelerinin dikkate alınması gerekir. Bu ilkeler, ağırlıklı olmak üzere şöyle özetlenebilir (Özoğlu ve Koç, 1996):

Ölçme ve değerlendirme hangi amaçla yapılırsa yapılsın, bir ölçme ve değerlendirme sürecinde bir takım değerlendirme ilkelerinin dikkate alınması gerekir. Bu ilkeler şöyle özetlenebilir:

Amaçlar ilkesi: Bir dersteki akademik başarı gelişiminin ölçülerek değerlendirilmesinde, okulun amaçları ve söz konusu dersin hedefleri esas alınmalıdır. Bu ilke uyarınca, ders içi ve ders dışı etkinliklerin hedeflerinin ayrıntılı biçimde analiz edilmesi gerekmektedir. Öğrenciden beklenen öğrenme ürünü ve davranış değişiklikleri tanımlanmalı ve betimlenmelidir.

Planlama ilkesi: Eğitim ve öğretim planlı bir etkinlik olduğuna göre, onun ana öğesi olan ölçme ve değerlendirme de bir plan çerçevesinde ele alınmalıdır. Öğretim sürecinin hangi aşamasında, hangi yöntemlerden yararlanılarak, nasıl bir ölçme ve değerlendirme yapılacağının dönem başında bir plana bağlanması ve ölçme değerlendirme etkinliklerinin de bu plana dayalı olarak geliştirilmesi gerekir.

Genişlik-kapsamlılık ilkesi: Değerlendirme etkinliklerinin planlanması ve yürütülmesinde öğrencilerin akademik başarılarını olumlu ve olumsuz yönde etkileyen kritik faktörlerin dikkate alınması gerekir. Bu ilke gereğince öğrencilerin sadece bilişsel özelliklerinin değil, duyuşsal özelliklerinin de ölçülmesi ve öğrenmelerle olan ilişkileri de dikkate alınmalıdır. Bu ilke kapsamında yürütülecek etkinliklerle öğrencilerin çalışma alışkanlıkları, okula-sınıfa karşı tutumlarının da değerlendirilmesi gerekir. Bunlar öğretim ortamını ve öğretim becerilerini zenginleştirecek çalışmaların yürütülmesine de yol gösterici olacaktır.

Bireysel farklılıklar ilkesi: Öğretimde akademik başarıyı ölçme ve değerlendirmenin temelinde bireysel farklılık kavramı bulunmaktadır. Ölçme ve değerlendirmede temel amaç, birey içi ve bireyler arası farklılıkları geçerli ve güvenilir yöntemlerle ortaya çıkarmak; elde edilen sonuçları, bireylerin en üst düzeyde akademik gelişimlerini sağlama yönünde kullanmaktır.

İşbirliği ilkesi: $\mathrm{Bu}$ ilkeye göre, tüm değerlendirme etkinliklerinin, özellikle öğrenci ve öğretmen işbirliğine dayalı olarak ele alınması gerekir. Öğrenme öğretme sürecine katılanların işbirliğine dayanan etkili bir ölçme ve değerlendirme yaklaşımları, akademik başarıyı ve kaliteyi arttırır. 
Devamlılık ilkesi: Eğitim-öğretim devam ederken yapılacak çeşitli gözlemlerin, ölçmelerin sürekli olması öğrenmenin nitelikli kılınmasına yönelik öğretim etkinliklerinin planlanmasını ve uygulanmasını sağlar. $\mathrm{Bu}$ ilke gereğince, ölçme ve değerlendirme sonuçlarının bileşkesini esas alan kararların isabetli olma, öğrenmeyi, kaliteyi ve performansı arttırma olasılı̆̆ 1 yüksektir.

Kendi kendini değerlendirme ilkesi: Öğrencilere, kendilerini değerlendirmeleri için olanak verilmesi, kendi güçlü ve zayıf yanlarının farkına varmasını sağlar hem de demokratik tutumların oluşmasına zemin hazırlar. Özetle değerlendirme sürecinde bu ilkeye dayalı uygulamalara yer vermek daha etkili ve sağlıklı bir eğitim-öğretim sürecinin oluşmasını ve başarının artmasını sağlar.

Ölçme araçlarında çeşitlilik ilkesi: Öğrencinin, eğitim amaçları çerçevesinde değerlendirilmesi gereken yönleri çok çeşitlidir. Her ölçme tekniğinin güçlü ve sınırlı özellikleri vardır. Çeşitlilik gösteren öğrenmeleri tek bir teknikle ölçmek ve değerlendirmek mümkün değildir. Ölçme ve değerlendirmede, ölçülmesi ve değerlendirilmesi gereken bilişsel becerilerin çeşitliliğine paralel olarak değişik ölçme tekniklerinden yararlanma gereği vardir.

Yukarıda yer alan ölçme ve değerlendirme ilkelerine dayalı olarak öğretmelerin eğitim uygulamalarına yönelik yapılan araştırmalara bakıldığında, bu konunun çeşitli açılardan ele alındığı görülmektedir. Öğretmenlerin ölçme uygulamalarına verdikleri önem ve bakış açılarını belirleme konusunda yapılan bir çalışmada öğretmenlerin, testleri, değerlendirmede en önemli araç olarak gördükleri saptanmıştır. Öğretmenlerin çoğu çoktan seçmeli testlerin, sınıf içinde rekabet ortamı yaratığı, etkileşim ortamı sağladığı, öğrencilerin bakış açılarını ve öğrenme ortamını geliştirdiği görüşündedirler. Bununla birlikte öğretmenler, testlerin, öğrencilerin üst düzey bilişsel davranışlarını ölçemediği ve öğrencileri değerlendirirken tek kaynak olmaması gerektiği yönünde görüş bildirmişlerdir (Gullickson, 1984).

Çeşitli demografik ve mesleki özelliklere göre öğretmenlerin ölçme ve değerlendirme uygulamalarının karşılaştırıldığ öğretmenlerin öğrenci merkezli değerlendirme tekniklerini, erkek öğretmenlerden daha sık kullandıkları; İlköğretim öğretmenlerinin, öğrenci merkezli değerlendirme yaklaşımlarını ortaöğretim öğretmenlerinden daha sık, geleneksel değerlendirme yöntemlerini ise orta öğretim öğretmenlerinden daha az kullandıkları bulunmuştur (Mertler, 2000; Zhang 
ve Burry-Stock, 2003). Ortaöğretimdeki branş öğretmenlerinin, ölçme araçlarından en çok yazılı sınavları kullandıkları; kısa cevap gerektiren testleri, çoktan seçmeli testleri, sözlü yoklamaları ve doğru yanlış testlerini ara sıra kullandıkları saptanmıştır (Çakan, 2004; Kaynak, 2000). Öğretmenlerin, ölçme ve değerlendirme işleminin amacını, öğrenciye not vererek başarısını belirleme olarak gördükleri, öğretmenlerin büyük çoğunluğunun çoktan seçmeli testler kullandıkları, bilgi ve kavrama düzeyini ölçen sorular sordukları, yazılı yoklamaları değerlendirirken, daha önceden hazırladıkları cevap anahtarından yararlandıkları saptanmıştır (Güven, 2001). Gelbal ve Kelecioğlu (2007) tarafından yapılan bir diğer araştırmada, öğretmenlerin en çok geleneksel değerlendirme yaklaşımlarını kullandıkları, öğrenci merkezli değerlendirme yaklaşımlarının öğretmenlerin yaklaşık yarıs1 tarafından "ara sıra" kullanıldı $\breve{g}$; akran değerlendirmelerinin ise katılımcıların yaklaşık \%80'i tarafından "ara sıra" uygulandığı ya da "hiç" uygulanmadığı saptanmıştır.

Bunun dişında eğitim fakültesinden mezun olan öğretmenlerin, ölçme ve değerlendirme konusunda kendilerini, diğer fakültelerden mezun öğretmenlere göre daha yeterli algıladıkları, öğretmenlerin ölçme ve değerlendirme davranışları arasında, değerlendirme dersi alanların lehine bir farklılık olduğu saptanmıştır (Aydın, 2001; Gümüş, 1981). Buna karşıı Ulutaş (2003) öğretmenlerin ölçme ve değerlendirme alanı ile ilgili yeterliklerini bir alan bilgisi testi ile saptadığ 1 araştırmasında, öğretmenlerin algılarına dayalı yeterliklerle, alan bilgisi testi ile saptanan yeterlikleri arasında düşük düzeyde bir ilişkinin olduğunu bulmuştur.

Sınıf öğretmenlerinin eğitim gereksinimlerinin belirlenmesine yönelik araştırmalarda, öğretmenlerin, ölçme ve değerlendirmeye ilişkin olarak eğitim gereksinimi duydukları alanlar da araştırılmıştır. Buna göre öğretmenlerin gözlem, çalışma dosyası, tartışma, deneyler, projeler, çalışma kâğıtları, öğrenci ürün dosyası ve performans değerlendirme konularında kendilerini yetersiz algıladıkları bulunmuștur (Gözütok, Ergün ve Karacaoğlu, 2005; Yaşar, Gültekin, Türkan, Yıldız ve Girmen, 2005).

Türkçe öğretim programının ölçme ve değerlendirme boyutuna ilişkin yapılan araştırmalarda, öğretmenlerin bazıları, değerlendirme ile ilgili yaşadıkları zorlukların ünite sonlarında verilen değerlendirme araçlarının karışık ve sürenin yetersiz olmasından ileri geldiğini vurgulamışlardır. Buna rağmen öğretmenlerin yarıdan fazlası, çeşitli değerlendirme tekniklerini kullanacak olmalarını ve süreç değerlendirmenin ön plana çıkmış olmasını olumlu bulduklarını belirtmişler; öğretmenlerden bazıları, öğrencilerin bireysel farklılıklarının dikkate alınarak değerlendirilmesinin, öğrencileri tanıma açısından yararlı olduğu yönünde görüş bildirmişlerdir (Collins, 2005; Coşkun, 2005; Özdaş ve diğerleri, 2005). 
Türkiye'nin de OECD üyesi ülke olarak katıldığı uluslararası öğrenci başarılarını belirleme çalışmalarında (TIMSS, PISA), öğrencilere Matematik ve Fen Bilgisi alanlarına yönelik testlerin yanında bu uygulamalara katılan öğrencilere ve öğretmenlerine eğitim-öğretim ve değerlendirme uygulamalarına yönelik durumu ortaya koyma amaçlı çeşitli anketler uygulanmıştır. Bu anket sonuçlarına göre, öğretmenlerin büyük çoğunluğu sınıf içi değerlendirmelerde öğretmen yapımı sınavlara ve ders kitaplarında yer alan değerlendirme testlerine yer vermektedir. Öğrencilerin üst düşünme becerilerini harekete geçirecek "veri toplama ve raporlaştırma" ya yönelik çalışmaların öğretmenlerin çoğunluğu tarafından "bazen" verildiği saptanmıştır. Yine öğretmenlerin yaklaşık yarısı ölçme ve değerlendirme sonuçlarını en sık "not verme" amaciyla kullandıklarını, öğrenciye ve aileye geri bildirim verme amacıyla "nadiren" kullandıklarını belirtmişlerdir (MEB, 2007; TIMSS, 2007a; TIMSS, 2007b).

Hayat Bilgisi ve Sosyal Bilgiler Programı'na ilişkin yapılan çalışmalarda ise, öğretmenlerin uygulamada en zorlandıkları kısmın ölçme ve değerlendirme olduğu, değerlendirme formlarının ve ölçeklerin değerlendirilmesinin çok uzun zaman almasının öğretmenleri olumsuz etkilediği belirtilmektedir. Değerlendirme sürecinde, birçok değerlendirme etkinliğinin bir arada kullanılmasının olumlu gibi görünmesine karşın, ögretmenlerin bu teknikler konusunda yeterli donanıma sahip olmaması ve sınıfların kalabalık olması, özellikle bireysel değerlendirme tekniklerinin kullanılmasını engellediği saptanmıştır (Aykaç ve Başar, 2005; Küçükahmet, 2005).

Öğretmenlerin yenilenen MEB programları kapsamında öğrenci merkezli ölçme ve değerlendirme yaklaşımlarına ilişkin bazı çalışmalar yapılmıştır. Bulgular, öğretmenlerin çoğunluğunun öğrenci merkezli ölçme ve değerlendirme tekniklerini tam olarak kullanmadıkları ve bu değerlendirme tekniklerini zor bulduklarını; yaklaşık yarısının ise bu teknikleri zaman alıcı teknikler olarak gördüklerini ortaya koymuştur. Ölçme ve değerlendirmede öğrenme, sürecinin değerlendirilmesi ile öğretim programlarında çok çeşitli formlar geliştirildiği ve önerildiğ (öz değerlendirme formu, davranış değerlendirme formu, araştırma formu, kariyer değerlendirme formu, proje değerlendirme formu ve ürün dosyası gibi), ancak, bunlardan elde edilecek bilgilerin nasıl kullanılacağı ve not verme konusu ile nasıl ilişkilendirileceğinin açı olmadığı belirtilmiştir. Ayrıca öğretmenlerin çoğunluğunun bu ölçme araçlarını kullanmayı bilmedikleri ve bu nedenle öğretmenlerin hizmet içi eğitimden geçmesi gerektiği saptanmıştır (Algan, 2008; Aydın, 2005; Erdoğan, 2005; Kanatlı, 2008; Merter, 2005; Sever, 2005; Tabak, 2007). 
Yukarıda belirtilen araştırmaların ortak noktası, yenilenen ilköğretim programının öngördüğü ölçme ve değerlendirme uygulamalarında, öğretmenlerin yeterli donanıma sahip olmamaları ve bu alanda hizmet içi eğitime gereksinim duymalarıdır. Ölçme ve değerlendirme uygulamalarının niteliğinin eğitim ve öğretimin niteliğini etkilemesi nedeniyle sınıf öğretmenlerinin ölçme ve değerlendirme ilkelerine dayalı uygulamaları gerçekleştirme durumun ortaya konması, önemlidir. $\mathrm{Bu}$ gerekçelerle araştırmanın problemini, sınıf öğretmenlerinin, ölçme ve değerlendirme ilkelerine dayalı çeşitli uygulamaları gerçekleştirme durumlarının kendi beyanlarına dayalı olarak saptanması oluşturmaktadır.

$\mathrm{Bu}$ araştırmanın genel amacı, sınıf öğretmenlerinin, ölçme ve değerlendirme ilkelerine dayalı uygulamaları gerçekleştirme sıklıklarını ve söz konusu uygulamaların çeşitli değişkenlerle ilişkisi olup olmadığını saptamaktır. $\mathrm{Bu}$ genel amaç doğrultusunda aşağıdaki sorulara yanıt aranmıştır:

1) Sınıf öğretmenleri, ölçme ve değerlendirme ilkelerine dayalı uygulamaları hangi sıklıkla gerçekleştirmektedirler?

2) Sınıf öğretmenlerinin ölçme ve değerlendirme ilkelerine dayalı uygulamaları gerçekleştirme sıklıkları ile cinsiyetleri arasında manidar bir ilişki var mıdır?

3) Sınıf öğretmenlerinin ölçme ve değerlendirme ilkelerine dayalı uygulamaları gerçekleştirme sıklıkları ile hizmet süreleri arasında manidar bir ilişki var mıdır?

4) Sınıf öğretmenlerinin ölçme ve değerlendirme ilkelerine dayalı uygulamaları gerçekleştirme sıklıkları ile mezun oldukları fakülte arasında manidar bir ilişki var mıdır?

5) Sınıf öğretmenlerinin ölçme ve değerlendirme ilkelerine dayalı uygulamaları gerçekleştirme sıklıkları ile sahip oldukları sınıf mevcudu arasında manidar bir ilişki var mıdır?

\section{YÖNTEM}

Sınıf öğretmenlerinin ölçme ve değerlendirme ilkelerine dayalı uygulamaları gerçekleştirme sıklıklarını çeşitli değişkenlere göre incelemek için yapılan bu araştırma, tarama modelinde bir araştırmadır.

\section{Katılımcilar}

Bu çalışmanın araştırma grubunu, 2006-2007 öğretim yılında, Aksaray ilinde görev yapan öğretmenlere yönelik olarak düzenlenen bir hizmet içi eğitim seminerine katılan 236 sınıf öğretmeni oluşturmaktadır. Sınıf öğretmenlerinin cinsiyet, sınıf mevcudu, hizmet süresi ve eğitim fakültesi mezunu olup olmama değișkenlerine göre dağılımı Çizelge 1'de verilmiştir. 
Çizelge 1. Öğretmenlerin Cinsiyet, Sınıf Mevcudu, Hizmet Süresi, Mezun Olunan Bölüm Değişkenlerine Göre Dağılımı

\begin{tabular}{llllllll}
\hline & \multirow{2}{*}{ Değişkenler } & \multicolumn{2}{l}{ Erkek } & \multicolumn{3}{c}{ Kadın } & \multicolumn{3}{c}{ Toplam } \\
& & $\mathbf{N}$ & $\mathbf{\%}$ & $\mathbf{N}$ & $\mathbf{\%}$ & $\mathbf{N}$ & $\mathbf{\%}$ \\
\hline \multirow{2}{*}{ Sinıf mevcudu } & 10-20 öğrenci & 38 & 16,1 & 38 & 16,1 & 76 & 32,2 \\
& 21-30 öğrenci & 37 & 15,7 & 47 & 19,9 & 84 & 35,6 \\
& 31 öğrenci ve üzeri & 55 & 23,3 & 21 & 8,9 & 76 & 32,2 \\
\hline \multirow{2}{*}{ Hizmet süresi } & 1-10 y1l & 69 & 29,2 & 57 & 24,2 & 126 & 53,4 \\
& 11 yıl ve üzeri & 61 & 25,8 & 49 & 20,8 & 110 & 46,6 \\
\hline \multirow{2}{*}{ Fakültte } & Eğitim Fakültesi & 87 & 36,9 & 58 & 24,5 & 145 & 61,4 \\
& Diğer & 43 & 18,3 & 48 & 20,3 & 91 & 38,6 \\
\hline \multirow{2}{*}{ TOPLAM } & & 130 & 55,1 & 106 & 44,9 & 236 & 100 \\
\hline
\end{tabular}

Çizelge 1'de görüldüğü gibi, öğretmenlerin \%55,1'i erkek, \%44,9'u ise kadındır. Sınıf mevcuduna göre öğretmenlerin dağılımı incelendiğinde, \%32,2'sinin 31 öğrenci ve üzeri öğrenciye sahip; \%35,6'sının 21-30 kişilik; $\% 32,2$ 'sinin ise 10-20 kişilik sınıflarda öğretmenlik yaptıkları görülmektedir. Araştırmanın başında, hizmet sürelerine göre öğretmenlerin, 1-5; 6-10; 11$15 ; 16$ yıl ve üzeri hizmet süresine göre gruplandırılması planlanmıştır. Ancak uygulama sonunda 1-5 y1llı ve 16 yıl ve üzeri hizmet süresine sahip öğretmenlerin frekansının oldukça düşük olduğu görülmüştür. Bu gerekçeyle öğretmenlerin hizmet süreleri iki kategoride toplanmıştır. Buna göre öğretmenlerin \%46,6's1 11 y1l ve üzeri, \%53,4'ü ise 1-10 y1l arasinda değişen hizmet sürelerine sahiptir. Sınıf öğretmeni olarak çalışanların \%61,4'ünün eğitim fakültesi mezunu, \%38,6'sının ise diğer fakültelerden mezun olduğu görülmektedir.

\section{Veri Toplama Aracı}

Öğretmenlerin ölçme ve değerlendirme ilkelerine ilişkin uygulamaları gerçekleştirme sıklıklarını saptamak için şimdiye kadar geliştirilmiş bir ölçme aracı bulunmadığı için, araştırmada kullanılmak üzere, araştırmacılar tarafindan, söz konusu ilkelere dayalı uygulamaları öğretmen görüşlerine göre saptamaya yönelik bir anket geliştirilmiştir.

Anketin geliştirilmesinde, anket geliştirme sürecindeki temel aşamalar izlenmiştir (Shaughnessy ve Zechmeister, 1997). Buna göre önce anketin amacı doğrultusunda kapsamı belirlenmiştir. Kapsamın belirlenmesinde, öğretmenlerin ölçme ve değerlendirme konusundaki yeterlikleri ile ilgili yerli ve yurtdışı alan yazındaki kavramsal açıklamalar ve araştırma temelli 
çalışmalar incelenmiştir. Bu inceleme sonucunda ölçme ve değerlendirmenin temel ilkelerine dayalı 42 ifade yazılmıştır. Hazırlanan 42 ifadeye ilişkin ölçme ve değerlendirme alanında çalışan akademisyen ve uygulamacı beş uzmandan, ifadelerde belirtilen uygulamaların ilgili değerlendirme ilkelerini temsil etme durumunu, dil ve anlatım özellikleri açısından uygunluğunu, verilen bir form üzerinde, açık uçlu ifadelerle değerlendirmeleri istenmiştir. Böylece anketin uzman kanısına dayalı geçerlik kanıtları sağlanmıştır. Anketin daha sonra ön denemesi, 2006 Haziran ayında Rize'de sinıf öğretmenlerine yönelik olarak düzenlenen bir hizmet içi eğitim seminerine çeşitli illerden gelerek katılmış 60 kişiden oluşan bir öğretmen grubu ile gerçekleştirilmiştir. Ankette anlaşılmayan ve sorunlu ifadeler, bu çalışma ile saptanarak anketten çıkarılmıs, bazı ifadelerde ise düzeltmeler yapılarak anketin 30 maddelik son hali oluşturulmuştur.

\section{İşlem}

Anketin 30 maddelik son hali araştırma grubundaki sınıf öğretmenlerine uygulanmıştır. Öğretmenler her bir madde ile belirtilen uygulamayı "gerçekleştirme sıklığını", "çoğu zaman, ara sıra, nadiren, hiçbir zaman" seçeneklerinden uygun olan birini işaretleyerek belirtmişlerdir. Öğretmenlerin, demografik bilgilerine ulaşmak için anketle birlikte verilen kişisel bilgi formu hazırlanmıştır. Kişisel bilgi formu ile, öğretmenlerin ölçme ve değerlendirme eğitimi alıp almama durumları, meslekte geçirdikleri hizmet süreleri, cinsiyetleri ve öğretmenlik yaptıkları sınıf mevcudu bilgisi derlenmiştir.

Anket maddelerine verilen tepkilerle toplanan bilgilerin verdiği ölçme bilgisi sınıflama düzeyindedir. Sürekli puan vermedikleri için anket verileri madde düzeyinde değerlendirilir. Aiken (1997)'e göre, anketlere verilen tepkilerin puanlanması basit bir kodlama ve siniflandırma konusudur. Bu tür kodlamalar, anketlere verilen yanttları matematiksel işlemlere (toplama, çıkarma, çarpma, bölme) uygun kılmaz. Bu çalışma kapsamında anket uygulamasindan elde edilen veriler SPSS 15,0 (Statistical Package for Social Sciencies) paket programı yardımıyla çözümlenmiştir Yukarıda sayılan gerekçelerle anket maddelerine verilen tepkilere ait frekans ve yüzdeler hesaplanmıştır. Araştırma soruları çerçevesinde öğretmenlerin demografik ve mesleki özellikleri ile anket maddelerine verdikleri tepkiler arasındaki ilişkinin/bağlantının ortaya konması için Cramer's V uygulanmıştır. Özdamar (2004, 206)'a göre, iki kategorik değişkenin ikiden fazla kategorisi olması durumunda, birlikte değişimi göstermek amacıyla Cramer V katsayısı kullanılır. Elde edilen istatistiklerin manidarlık testinde .05 düzeyi esas alınmıştır. 


\section{BULGULAR VE YORUMLAR}

$\mathrm{Bu}$ bölümde, araştırmanın amacı çerçevesinde, araştırma sorularına ilişkin bulgular özetlenmiş ve yorumlanmıştır.

1) Sınıf öğretmenleri, ölçme ve değerlendirme ilkelerine dayalı uygulamaları hangi sıklıkla gerçekleştirmektedirler?

Öğretmenlerin ölçme ve değerlendirme ilkelerinden amaçlar ilkesine dayalı uygulamaları gerçekleştirme sıklıklarına ilişkin frekans ve yüzde değerleri Çizelge 2'de verilmiştir.

Çizelge 2. Öğretmenlerin Amaçlar İlkesine Dayalı Uygulamaları Gerçekleştirme Sıklıklarına Ait Frekans ve Yüzde Değerleri

\begin{tabular}{lllllll}
\hline İfadeler/Durumlar & & & $\begin{array}{l}\text { Çoğu } \\
\text { zaman }\end{array}$ & $\begin{array}{l}\text { Ara } \\
\text { sıra }\end{array}$ & Nadiren & $\begin{array}{l}\text { Hiçbir } \\
\text { zaman }\end{array}$ \\
\hline $\begin{array}{l}\text { 1)Dersin amaçlarını, dönem } \\
\text { öğrenciye yazılı olarak bildirmek. }\end{array}$ & başında & $\mathrm{f}$ & 46 & 95 & 44 & 51 \\
\hline $\begin{array}{l}\text { 2) Öğrencinin çeşitli etkinliklerdeki } \\
\text { başarısını, konunun kazanımlarına }\end{array}$ & $\mathrm{f}$ & 19,5 & 40,3 & 18,6 & 21,6 \\
\begin{tabular}{l} 
değerlendirmek. \\
\hline
\end{tabular} & & $\%$ & 57,6 & 34,4 & 7,2 & 0,8 \\
\hline
\end{tabular}

Öğretmenlerin yarıdan biraz azı, "dersin amaçlarının dönem başında öğrenciye yazılı olarak bildirilmesi”nin eğitim öğretim etkinlikleri içinde uygulanma sıklığını, "ara sıra" tepkisiyle belirtmişlerdir. "Öğrencinin çeşitli etkinliklerdeki başarısının, konunun kazanımlarına göre değerlendirilmesi" konusunda ise öğretmenlerin yarıdan biraz fazlası "çoğu zaman" seçeneğine yönelirken; çok küçük bir kesimi "nadiren" ve "hiçbir zaman" seçeneğine yönelmişlerdir. Genel olarak, ölçme ve değerlendirmenin amaçlar ilkesine dayalı olarak yukarıda verilen durumların, öğretmenlerin çoğunluğu tarafından yeterince gerçekleştirilmediği saptanmıştır.

Öğretmenlerin, ölçme ve değerlendirme ilkelerinden planlama ilkesine dayalı uygulamaları eğitim öğretim etkinlikleri içerisinde gerçekleştirme sıklıklarına ait frekans ve yüzde değerleri Çizelge 3'te verilmiştir. 
Çizelge 3. Öğretmenlerin Planlama İlkesine Dayalı Uygulamaları Gerçekleştirme Sıklıklarına Ait Frekans ve Yüzde Değerleri

\begin{tabular}{|c|c|c|c|c|c|}
\hline İfadeler/Durumlar & & $\begin{array}{c}\text { Çoğu } \\
\text { zaman }\end{array}$ & $\begin{array}{l}\text { Ara } \\
\text { sira }\end{array}$ & Nadiren & $\begin{array}{l}\text { Hiçbir } \\
\text { zaman }\end{array}$ \\
\hline \multirow{2}{*}{$\begin{array}{l}\text { 3) Ödevler ve projeler için yeterli süreyi } \\
\text { önceden belirleyerek öğrencilere } \\
\text { duyurmak. }\end{array}$} & $\mathrm{f}$ & 166 & 50 & 14 & 6 \\
\hline & $\%$ & 70,3 & 21,2 & 6 & 2,5 \\
\hline \multirow{2}{*}{$\begin{array}{l}\text { 4) Öğretim y1lı başında, öğretim süreci } \\
\text { boyunca uygulanacak uygun ölçme ve } \\
\text { değerlendirme etkinliklerinin planını } \\
\text { yapmak. }\end{array}$} & $\mathrm{f}$ & 132 & 71 & 25 & 8 \\
\hline & $\%$ & 55,9 & 30,1 & 10,6 & 3,4 \\
\hline
\end{tabular}

Çizelge 3'e göre, öğretmenlerin büyük bir kısmı çoğu zaman, ödevler ve projeler için yeterli süreyi önceden belirleyerek öğrencilere duyurmaktadırlar. Öğretmenlerin yarıdan biraz fazlası, öğretim yılı başında ölçme ve değerlendirme etkinliklerinin planını "çoğu zaman" yaptıklarını, yarıdan oldukça azı ise, "ara sıra" yaptıklarını belirtmektedirler. Başka bir deyişle değerlendirme etkinliklerinin öğretmenler tarafindan kısmen planlı olarak yürütüldüğü sonucuna ulaşılabilir.

Öğretmenlerin, ölçme ve değerlendirme ilkelerinden genişlikkapsamlılık ilkesine dayalı uygulamaları eğitim öğretim etkinlikleri içerisinde gerçekleştirme sıklıklarına ait frekans ve yüzde değerleri Çizelge 4 'te verilmiştir.

Çizelge 4. Öğretmenlerin Genişlik-Kapsamlılık İlkesine Dayalı Uygulamaları Gerçekleştirme Sıklıklarına Ait Frekans ve Yüzde Değerleri

\begin{tabular}{llllll}
\hline İfadeler/Durumlar & & $\begin{array}{l}\text { Çoğu } \\
\text { zaman }\end{array}$ & $\begin{array}{l}\text { Ara } \\
\text { sıra }\end{array}$ & Nadiren & $\begin{array}{l}\text { Hiçbir } \\
\text { zaman }\end{array}$ \\
\hline $\begin{array}{l}\text { 5) Sınav sorularını, öğrenciyi üst düzey } \\
\text { düşünmeye sevk edecek düzeyde hazırlamak. }\end{array}$ & $\begin{array}{l}\mathrm{f} \\
\%\end{array}$ & $\begin{array}{l}128 \\
54,2\end{array}$ & $\begin{array}{l}80 \\
33,9\end{array}$ & $\begin{array}{l}25 \\
10,6\end{array}$ & 3 \\
\hline $\begin{array}{l}\text { 6) Sinav sorularını ve değerlendirme } \\
\text { etkinliklerini, gündelik yaşam durumlarına } \\
\text { dayalı olarak hazırlamak. }\end{array}$ & $\mathrm{f}$ & 131 & 84 & 18 & 2 \\
\hline $\begin{array}{l}\text { 7) Değerlendirme etkinliklerinden elde edilen } \\
\text { sonuçları, telafi edilmesi gereken konuları } \\
\text { saptamak için kullanmak. }\end{array}$ & $\mathrm{f}$ & 120 & 90 & 25 & 1 \\
\hline
\end{tabular}

Çizelge 4'e göre, "sınav sorularını, öğrenciyi üst düzey düşünmeye sevk edecek düzeyde ve gündelik yaşam durumlarına dayalı olarak hazırlama" ve "değerlendirme etkinliklerinden elde edilen sonuçları, telafi edilmesi gereken konuları saptamak için kullanma" konusunda, öğretmenlerin 
yaklaşık yarısı, "çoğu zaman"; yarıdan oldukça azı "ara sıra"; küçük bir oranı ise "nadiren" uyguladıklarını veya "hiçbir zaman" uygulamadıklarını bildirmişledir. Buna göre, ölçme ve değerlendirmenin genişlik kapsamlılık ilkesine dayalı olarak yukarıda verilen durumların, öğretmenlerin yaklaşık yarısı tarafından uygulandığı, diğer yarısı tarafından ise gerçekleştirildiği ya da çok az gerçekleştirildiği saptanmıştır. Bu bulgu ile TIMSS, PISA gibi uluslar arası çapta uygulanan Matematik ve Fen Bilgisi sinavlarında Türk öğrencilerinin üst düzey düşünme becerilerini gerektiren sorularda neden başarısız oldukları sorusuna kısmen yanıt verebilir (MEB, 2007; TIMSS, 2007a; TIMSS, 2007b). Öğrencilerin sınıf içi değerlendirme uygulamalarında üst düzey düşünme becerilerini kullanmalarını gerektirecek durumlarla karşılaşmamaları onları bu becerilerin ölçüldüğü durum belirleme çalışmalarında dezavantajlı kılmış olabilir.

Ölçme ve değerlendirme ilkelerinden bireysel farklılıklar ilkesine dayalı uygulamaları eğitim öğretim etkinlikleri içerisinde gerçekleştirme sıklıklarına ait frekans ve yüzde değerleri Çizelge 5'te verilmiştir.

Çizelge 5. Öğretmenlerin Bireysel Farklı1ıklar İlkesine Dayalı Uygulamaları Gerçekleştirme Sıklıklarına Ait Frekans ve Yüzde Değerleri

\begin{tabular}{|c|c|c|c|c|c|}
\hline İfadeler/Durumlar & & $\begin{array}{c}\text { Çoğu } \\
\text { zaman }\end{array}$ & $\begin{array}{l}\text { Ara } \\
\text { sira }\end{array}$ & Nadiren & $\begin{array}{l}\text { Hiçbir } \\
\text { zaman }\end{array}$ \\
\hline $\begin{array}{lll}\text { 8) Öğrencilerin güçlü } & \text { ve geliştirilmesi } \\
\text { gereken yönlerini } & \text { ortaya clkarıc }\end{array}$ & $\mathrm{f}$ & 112 & 94 & 27 & 3 \\
\hline değerlendirmeler yapmak. & $\%$ & 47,5 & 39,8 & 11,4 & 1,3 \\
\hline $\begin{array}{l}\text { 9) Öğrencilerin başarısızlı nedenlerini } \\
\text { ortaya koyacak gözlemler yapmak. }\end{array}$ & $\begin{array}{c}\mathrm{f} \\
\% \\
\%\end{array}$ & $\begin{array}{r}108 \\
45,7 \\
\end{array}$ & $\begin{array}{r}104 \\
44,1 \\
\end{array}$ & $\begin{array}{l}21 \\
8,9 \\
\end{array}$ & $\begin{array}{c}3 \\
1,3 \\
\end{array}$ \\
\hline
\end{tabular}

Çizelge 5'te verilen iki ifadeyle ilgili olarak ölçme ve değerlendirmenin bireysel farklılıklar ilkesine dayalı olarak yukarıda verilen uygulamaların öğretmenlerin yaklaşık yarısı tarafından gerçekleştirildiği, diğer yarısı tarafından ise yeterince gerçekleştirilmediği saptanmıştır.

Ölçme ve değerlendirme ilkelerinden işbirliği ilkesine dayalı uygulamaları eğitim öğretim etkinlikleri içerisinde gerçekleştirme sıklıklarına ait frekans ve yüzde değerleri Çizelge 6'da verilmiştir. 
Çizelge 6. Öğretmenlerin İşbirliği İlkesine Dayalı Uygulamaları Gerçekleştirme Sıklıklarına Ait Frekans ve Yüzde Değerleri

\begin{tabular}{|c|c|c|c|c|c|}
\hline İfadeler/Durumlar & & $\begin{array}{c}\text { Çoğu } \\
\text { zaman }\end{array}$ & $\begin{array}{l}\text { Ara } \\
\text { sira }\end{array}$ & Nadiren & $\begin{array}{l}\text { Hiçbir } \\
\text { zaman }\end{array}$ \\
\hline 10) Öğrencilere konunun başında o & $\mathrm{f}$ & 83 & 101 & 48 & 4 \\
\hline $\begin{array}{l}\text { konudan neler öğrenmeyi beklediklerini } \\
\text { sormak. }\end{array}$ & $\%$ & 35,2 & 42,8 & 20,3 & 1,7 \\
\hline $\begin{array}{l}\text { 11) Değerlendirme sonuçlarına ve } \\
\text { gözlemlere dayalı olarak, öğrencilerin } \\
\text { gelişimleri hakkında velilere } \\
\text { geribildirimlerde bulunmak. }\end{array}$ & $\%$ & 30,9 & 44,9 & 20,8 & $\begin{array}{c}8 \\
3,4\end{array}$ \\
\hline $\begin{array}{l}\text { 12) Değerlendirme sonuçlarına ve } \\
\text { gözlemlere dayalı olarak, ögrencilere } \\
\text { gelişimleri hakkında geribildirim } \\
\text { vermek. }\end{array}$ & $\%$ & 43,2 & 39,8 & 14,8 & 2,2 \\
\hline
\end{tabular}

Çizelge 6'ya göre, öğretmenlerden bu durumları "çoğu zaman" uyguladıklarını belirtenlerin oranı azdır. Genel olarak değerlendirildiğinde, öğretmenlerin çoğunluğunun (\%60 ve civarı) işbirliği ilkesine dayalı uygulamaları yeterince gerçekleştirmedikleri sonucuna ulaşılabilir.

Öğretmenlerin, ölçme ve değerlendirme ilkelerinden kendi kendini değerlendirme ilkesine dayalı uygulamaları eğitim öğretim etkinlikleri içerisinde gerçekleştirme sıklıklarına ait frekans ve yüzde değerleri Çizelge 7'de verilmiştir.

Çizelge 7. Öğretmenlerin Kendi Kendini Değerlendirme İlkesine Dayalı Uygulamaları Gerçekleştirme Sıklıklarına Ait Frekans ve Yüzde Değerleri

\begin{tabular}{|c|c|c|c|c|c|}
\hline İfadeler/Durumlar & & $\begin{array}{c}\text { Çoğu } \\
\text { zaman }\end{array}$ & $\begin{array}{l}\text { Ara } \\
\text { sira }\end{array}$ & Nadiren & $\begin{array}{l}\text { Hiçbir } \\
\text { zaman }\end{array}$ \\
\hline \multirow{2}{*}{$\begin{array}{l}\text { 13) Öğrencilere puanlanmış sınav kâğıtlarını } \\
\text { dağıtarak, verdikleri yanıtlara ilişkin geri } \\
\text { bildirim almalarını sağlamak. }\end{array}$} & $\mathrm{f}$ & 129 & 69 & 30 & 8 \\
\hline & $\%$ & 54,7 & 29,2 & 12,7 & 3,4 \\
\hline \multirow{2}{*}{$\begin{array}{l}\text { 14) Öğrencilerin grupla yaptıkları ödev ve/veya } \\
\text { proje çalışmalarında, birbirlerinin } \\
\text { performanslarını değerlendirme olanağı vermek. }\end{array}$} & $\mathrm{f}$ & 50 & 112 & 46 & 28 \\
\hline & $\%$ & 21,2 & 47,5 & 19,4 & 11,9 \\
\hline \multirow{2}{*}{$\begin{array}{l}\text { 15) Öğrencilerin güçlü ve zayıf yönlerini } \\
\text { tanımaları için, çeşitli öğretim etkinlikleri } \\
\text { sırasında ve sonrasında, } \\
\text { değerlendirme olanağı vermek. }\end{array}$} & $\mathrm{f}$ & 63 & 114 & 51 & 8 \\
\hline & $\%$ & 26,7 & 48,3 & 21,6 & 3,4 \\
\hline
\end{tabular}


Çizelge 7'ye göre, öğretmenlerin yaklaşık yarısı, öğrencilere puanlanmış sınav kâğıtlarını dağıtarak, verdikleri yanıtlara ilişkin geri bildirim almalarını çoğu zaman sağlamaktadırlar. Öğrencilerin kendilerini değerlendirme olanağını "ara sıra" sağladıkları saptanmıştır. Bu uygulamaları nadiren gerçekleştirenler ve hiç gerçekleştirmeyenler, grubun çok az bir bölümünü oluşturmaktadırlar. Buna göre, öğretmenlerin çoğunluğu tarafından, öğrencilere kendi kendini değerlendirme olanağının yeterince tanınmadığı saptanmıştır.

Öğretmenlerin, ölçme ve değerlendirme ilkelerinden devamlılık ilkesine dayalı uygulamaları eğitim öğretim etkinlikleri içerisinde gerçekleştirme sıklıklarına ait frekans ve yüzde değerleri Çizelge 8'de verilmiştir.

Çizelge 8. Öğretmenlerin Devamlılık İlkesine Dayalı Uygulamaları Gerçekleştirme Sıklıklarına Ait Frekans ve Yüzde Değerleri

\begin{tabular}{|c|c|c|c|c|c|}
\hline İfadeler/Durumlar & & $\begin{array}{c}\text { Çoğu } \\
\text { zaman }\end{array}$ & $\begin{array}{l}\text { Ara } \\
\text { sira }\end{array}$ & Nadiren & $\begin{array}{l}\text { Hiçbir } \\
\text { zaman }\end{array}$ \\
\hline \multirow{2}{*}{$\begin{array}{l}\text { 16) Öğrencilerin dersteki başarısını nota } \\
\text { çevirirken, dönem boyunca yapılan ölçme ve } \\
\text { değerlendirme etkinliklerine ait sonuçları, } \\
\text { belirli ağırlıklarla nota katmak. }\end{array}$} & $\mathrm{f}$ & 118 & 80 & 34 & 4 \\
\hline & $\%$ & 50,5 & 33,5 & 14,3 & 1,7 \\
\hline \multirow{2}{*}{$\begin{array}{l}\text { 17) Öğretim sürecinde öğrenci gelişimindeki } \\
\text { eksiklerini görebilmek için } \quad \text { küçük } \\
\text { değerlendirme etkinlikleri yapmak. }\end{array}$} & $f$ & 68 & 81 & 28 & 59 \\
\hline & $\%$ & 28,8 & 34,3 & 11,9 & 25 \\
\hline
\end{tabular}

Çizelge 8'e göre, öğretmenlerin yaklaşık yarısı, “çoğu zaman”, dönem boyunca yapılan ölçme ve değerlendirme etkinliklerine ait sonuçların tümünü belirli ağırlıklarla nota kattıklarını belirtmektedirler. Bu uygulamayı "gerçekleştirmeyenler ve nadiren uygulayanlar" ise öğretmenlerin çok küçük bir kesimini oluşturmaktadır. Grubun \% 34,3'ü, öğretim sürecinde küçükkısa değerlendirme etkinliklerinin "ara sıra"; \%28,8'i ise bu uygulamayı "çoğu zaman" uyguladıklarını ifade etmişlerdir. Buna göre, öğretmenlerin yarıdan azı, ölçme ve değerlendirmenin devamlılık ilkesine ilişkin olarak yukarıda verilen durumları eğitim-öğretim sürecinde uygularken, diğerleri yeterince uygulamamaktadırlar.

Sınıf öğretmenlerinin ölçme ve değerlendirme ilkelerinden ölçme araçlarında çeşitlilik ilkesine dayalı uygulamaları eğitim öğretim etkinlikleri içerisinde gerçekleştirme sıklıklarına ait frekans ve yüzde değerleri Çizelge 9'da verilmiştir. 
Çizelge 9. Öğretmenlerin Ölçme Araçlarında Çeşitlilik İlkesine Dayalı Uygulamaları Gerçekleştirme Sıklıklarına Ait Frekans ve Yüzde Değerleri

\begin{tabular}{|c|c|c|c|c|c|}
\hline İfadeler/Durumlar & & $\begin{array}{l}\text { Çoğu } \\
\text { zaman }\end{array}$ & $\begin{array}{l}\text { Ara } \\
\text { sira }\end{array}$ & Nadiren & $\begin{array}{l}\text { Hiçbir } \\
\text { zaman }\end{array}$ \\
\hline $\begin{array}{l}\text { 18) Öğrencilerin, problem çözmelerini } \\
\text { ve eleştirel düşünmelerini gerektiren } \\
\text { sorulara verdikleri yanıtları dereceli } \\
\text { puanlama anahtarı ile değerlendirmek. }\end{array}$ & $\%$ & 15,3 & 43,2 & 28,8 & 12,7 \\
\hline \multirow{2}{*}{$\begin{array}{l}\text { 19) Öğrencilerin derse karşı tutumunu } \\
\text { değerlendirmede tutum ölçeklerinden } \\
\text { yararlanmak. }\end{array}$} & $\mathrm{f}$ & 49 & 101 & 59 & 27 \\
\hline & $\%$ & 20,8 & 42,8 & 25 & 11,4 \\
\hline \multirow{2}{*}{$\begin{array}{l}\text { 20) Öğrencilere, gösteri veya sergileme } \\
\text { türü, yaratıcılıklarını ortaya } \\
\text { koyacakları etkinlikleri gerçekleştirme } \\
\text { olanağı sağlamak. }\end{array}$} & $\mathrm{f}$ & 84 & 100 & 46 & 6 \\
\hline & $\%$ & 35,6 & 42,4 & 19,5 & 2,5 \\
\hline \multirow{2}{*}{$\begin{array}{l}\text { 21) Öğrencilerin bedensel becerilerini } \\
\text { ve yeteneklerini değerlendirmek. }\end{array}$} & $\mathrm{f}$ & 83 & 105 & 42 & 6 \\
\hline & $\%$ & 35,2 & 44,5 & 17,8 & 2,5 \\
\hline \multirow{2}{*}{$\begin{array}{l}\text { 22) Kavramların anlaşılırlı̆̆ını } \\
\text { değerlendirmede kavram haritalarını } \\
\text { kullanmak. }\end{array}$} & $\mathrm{f}$ & 27 & 89 & 94 & 26 \\
\hline & $\%$ & 11,4 & 37,7 & 39,8 & 11,1 \\
\hline \multirow{2}{*}{$\begin{array}{l}\text { 23) Öğrencilerden gerçek yaşam } \\
\text { durumlarına dayalı problemlere ilişkin } \\
\text { çözüm üretmelerini isteyen sinıf içi } \\
\text { etkinlikler yapmak. }\end{array}$} & $\mathrm{f}$ & 63 & 80 & 88 & 5 \\
\hline & $\%$ & 26,7 & 33,9 & 37,3 & 2,1 \\
\hline \multirow{2}{*}{$\begin{array}{l}\text { 24) Öğrencilerin anlama düzeylerini } \\
\text { değerlendirmek için, kendileriyle küçük } \\
\text { gruplar halinde görüşmeler yapmak. }\end{array}$} & $\mathrm{f}$ & 25 & 86 & 110 & 15 \\
\hline & $\%$ & 10,6 & 36,4 & 46,6 & 6,4 \\
\hline \multirow{2}{*}{ 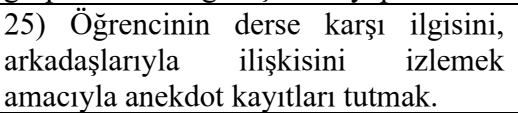 } & $\mathrm{f}$ & 10 & 78 & 86 & 61 \\
\hline & $\%$ & 4,2 & 33,1 & 36,4 & 26,3 \\
\hline \multirow{2}{*}{$\begin{array}{l}\text { 26) Öğrencilerin güncel bir konu } \\
\text { hakkındaki tahminlerini ve yorumlarını } \\
\text { ifade etmelerini sağlayıcı tartışma } \\
\text { grupları oluşturmak. }\end{array}$} & $\mathrm{f}$ & 66 & 98 & 58 & 14 \\
\hline & $\%$ & 28 & 41,5 & 24,6 & 5,9 \\
\hline \multirow{2}{*}{$\begin{array}{l}\text { 27) Öğrencilerin derste yaptıkları } \\
\text { etkinlik, çalışma yaprağı ve ödev } \\
\text { çalışmalarından en çok beğendiklerini, } \\
\text { gerekçelerini belirterek bir dosyada } \\
\text { toplamalarını sağlamak. }\end{array}$} & $\mathrm{f}$ & 34 & 83 & 79 & 40 \\
\hline & $\%$ & 14,4 & 35,2 & 33,5 & 16,9 \\
\hline \multirow{2}{*}{$\begin{array}{l}\text { 28) Öğrencilerin araştırma ve } \\
\text { sorgulama becerilerini geliştirmek için } \\
\text { proje çalışmaları yaptırmak. }\end{array}$} & $\mathrm{f}$ & 53 & 106 & 67 & 10 \\
\hline & $\%$ & 22,5 & 44,9 & 28,4 & 4,2 \\
\hline \multirow{2}{*}{$\begin{array}{l}\text { 29) Öğrencilerin sunu becerilerinin } \\
\text { arkadaşları tarafından gözlem formları } \\
\text { ile değerlendirilmesini sağlamak. }\end{array}$} & $\mathrm{f}$ & 13 & 82 & 84 & 57 \\
\hline & $\%$ & 5,5 & 34,7 & 35,6 & 24,2 \\
\hline \multirow{2}{*}{$\begin{array}{l}\text { 30) Çoktan seçmeli, kısa cevap, } \\
\text { eşleştirme ve doğru-yanlış türündeki } \\
\text { sorulara yer vermek. }\end{array}$} & $f$ & 154 & 62 & 16 & 4 \\
\hline & $\%$ & 65,3 & 26,2 & 6,8 & 1,7 \\
\hline
\end{tabular}


Çizelge 9'a göre, ölçme araçlarında çeşitlilik ilkesi içerisinde yer alan uygulamaların gerçekleştirilme sıklıkları incelendiğinde "ara sıra" ve "nadiren" seçeneklerine yı̆̆ılmanın olduğu göze çarpmaktadır. Öğretmenler, klasik değerlendirme yaklaşımlarını (çoktan seçmeli, kısa cevap, eşleştirme ve doğru-yanlış türündeki sorularla yazılı sınav yapma) çoğu zaman uygulamaktadırlar. Hiç gerçekleşmeyen uygulamalar ise, sunu becerileri için akran değerlendirmeleri yaptırmak ve anekdot kayıtları tutmaktır. Dereceli puanlama anahtarı (rubrik) ile değerlendirmeler yapmak, tutum ölçeklerinden yararlanmak, öğrencilere, gösteri veya sergileme türü, yaratıc1lıklarını ortaya koyacakları etkinlikleri gerçekleştirme olanağ sağlamak, öğrencilerin bedensel becerilerini ve yeteneklerini sergiledikleri etkinlikleri değerlendirmek, tartışma grupları oluşturmak, proje çalışmaları yaptırmak ise genelde "ara sıra" gerçekleştirilen ölçme ve değerlendirme uygulamalarıdır. Genel olarak değerlendirildiğinde, öğretmenlerin, ölçme araçlarında çeşitlilik ilkesine ilişkin uygulamalardan, sürece yayılmış değerlendirme etkinliklerini yeterince uygulamadıkları sonucuna ulaşılabilir.

2) Sınıf öğretmenlerinin, ölçme ve değerlendirme ilkelerine dayalı uygulamaları eğitim öğretim etkinlikleri içinde gerçekleştirme sıklığı ile cinsiyetleri arasında manidar bir ilişki var mıdır?

$\mathrm{Bu}$ araştırma sorusunu yanıtlamak için, ilgili değişkenlere ilişkin Cramer V değerleri hesaplanmıştır. Bu hesaplama yapılırken, gözeneklerinde 5'ten küçük değerler alan "nadiren" ve "hiçbir zaman" seçenekleri birleştirilmiştir. Yapılan istatistikler sonucu elde edilen bulgular Çizelge 10'da özetlenmiştir.

Çizelge 10. Öğretmenlerin Cinsiyetlerine Göre Ölçme ve Değerlendirme İlkelerine Dayalı Uygulamaları Gerçekleştirme Sıklıklarına Ait Cramer V Değerleri

\begin{tabular}{lllllllll}
\hline $\begin{array}{l}\text { Madde } \\
\text { No }\end{array}$ & $\begin{array}{l}\text { Cramer } \\
\text { V }\end{array}$ & $\mathbf{p}$ & $\begin{array}{l}\text { Madde } \\
\text { No }\end{array}$ & $\begin{array}{l}\text { Cramer } \\
\mathbf{V}\end{array}$ & $\mathbf{p}$ & $\begin{array}{l}\text { Madde } \\
\text { No }\end{array}$ & $\begin{array}{l}\text { Cramer } \\
\mathbf{V}\end{array}$ & $\mathbf{p}$ \\
\hline 1 &, 08 &, 43 & $\mathbf{1 1}$ & $\mathbf{, 1 7}$ & $\mathbf{, 0 2 *}$ & 21 &, 12 &, 18 \\
2 &, 08 &, 40 & 12 &, 14 &, 09 & $\mathbf{2 2}$ & $\mathbf{, 1 6}$ & $\mathbf{, 0 3 *}$ \\
3 &, 08 &, 44 & 13 &, 13 &, 11 & 23 &, 13 &, 14 \\
4 &, 04 &, 78 & 14 &, 06 &, 58 & 24 &, 05 &, 73 \\
5 &, 03 &, 84 & 15 &, 11 &, 21 & 25 &, 11 &, 41 \\
6 &, 13 &, 11 & 16 &, 15 &, 06 & 26 &, 08 &, 44 \\
$\mathbf{7}$ & $\mathbf{2 6}$ & $\mathbf{, 0 0 *}$ & 17 &, 13 &, 14 & $\mathbf{2 7}$ & $\mathbf{, 2 7}$ & $\mathbf{, 0 0 *}$ \\
8 &, 08 &, 45 & 18 &, 11 &, 21 & 28 &, 04 &, 79 \\
$\mathbf{9}$ & $\mathbf{2 3}$ & $\mathbf{, 0 0 *}$ & 19 &, 10 &, 31 & 29 &, 09 &, 34 \\
10 &, 13 &, 13 & 20 &, 13 &, 13 & 30 &, 12 &, 17 \\
\hline
\end{tabular}

$* \mathrm{p}<.05$ 
Çizelge 10'a göre, ölçme değerlendirme uygulamalarının gerçekleşme sıklık düzeyleri ile öğretmenlerin cinsiyetleri arasında; 7, 9, 11, 22 ve 27. maddeler için manidar ilișkiler bulunurken, diğer maddeler için manidar bir ilișki olmadığı saptanmıștır. Öğretmenlerin, ölçme değerlendirme ilkelerine dayalı uygulamalarındaki sıklık düzeyleri ile cinsiyetleri arasında manidar ilişkinin saptandığı maddelerde, sıklık düzeylerinin cinsiyete göre dağılımı Çizelge 11'de verilmiştir.

Çizelge 11. Öğretmenlerin Cinsiyete Göre Ölçme ve Değerlendirme İlkelerine Dayalı Uygulamaları Gerçekleştirme Sıklıklarına Ait Frekans ve Yüzde Değerleri

\begin{tabular}{|c|c|c|c|c|c|c|c|}
\hline \multirow[t]{2}{*}{ İfadeler/Durumlar } & & \multicolumn{2}{|c|}{$\begin{array}{l}\text { Çoğu } \\
\text { zaman }\end{array}$} & \multicolumn{2}{|c|}{ Ara sira } & \multicolumn{2}{|c|}{$\begin{array}{l}\text { Nadiren } \\
\text { veya hiçbi } \\
\text { zaman }\end{array}$} \\
\hline & & $\mathbf{f}$ & $\%$ & f & $\%$ & f & $\%$ \\
\hline $\begin{array}{l}\text { 7)Değerlendirme etkinliklerinden } \\
\text { edde } \\
\text { edilen sonuçları, öğretim sürecinde telafi }\end{array}$ & $\mathrm{E}$ & 51 & 39,2 & 59 & 45,4 & 20 & 15,4 \\
\hline $\begin{array}{l}\text { edilmesi gereken konuları saptamak için } \\
\text { kullanmak. }\end{array}$ & $\mathrm{K}$ & 69 & 65,1 & 31 & 29,2 & 6 & 5,7 \\
\hline 9) Öğrencilerin başarısızlık nedenlerini & $\mathrm{E}$ & 47 & 36,2 & 64 & 49,2 & 19 & 14,6 \\
\hline ortaya koyacak gözlemler yapmak. & & 6 & & 40 & & 5 & \\
\hline $\begin{array}{l}\text { 11) Değerlendirme sonuçlarına ve } \\
\text { gözlemlerine dayalı olarak, öğrencilerin }\end{array}$ & $\mathrm{E}$ & 31 & 23,8 & 62 & 47,7 & 37 & 28,5 \\
\hline $\begin{array}{l}\text { gelişimleri hakkında } \\
\text { geribildirimlerde bulunmak. }\end{array}$ & $V$ & 42 & 39,6 & 44 & 41,5 & 20 & 18,9 \\
\hline anlaşılırlığını & $\mathrm{E}$ & 13 & 10 & 41 & 31,5 & 76 & 58,5 \\
\hline $\begin{array}{l}\text { değerlendirmede kavram haritaların } \\
\text { kullanmak. }\end{array}$ & K & 14 & 13,2 & 41 & 45,3 & 44 & 41,5 \\
\hline $\begin{array}{l}\text { 27) Öğrencilerin derste yaptıkları etkinlik, } \\
\text { çalışma yaprağ } 1 \text { ve ödev çalışmalarından en }\end{array}$ & $\mathrm{E}$ & 9 & 6,9 & 57 & 43,8 & 64 & 49,2 \\
\hline bir dosyada toplamalarını sağlamak. & $\mathrm{K}$ & 25 & 23,6 & 26 & 24,5 & 55 & 51,9 \\
\hline
\end{tabular}

Çizelge 11'de yer alan ölçme ve değerlendirme uygulamalarındaki yüzde ve frekans değerleri incelendiğinde, kadın öğretmenlerin bu durumları erkeklere oranla daha sık gerçekleştirdikleri anlaşılmaktadır.

3) Sınıf öğretmenlerinin, ölçme ve değerlendirme ilkelerine dayalı uygulamaları eğitim öğretim etkinlikleri içinde gerçekleştirme sıklıkları ile hizmet süreleri arasında manidar bir ilişki var mıdır?

$\mathrm{Bu}$ araştırma sorusunu yanıtlamak için, ilgili değişkenlere ilişskin CramerV değerleri hesaplanmıştır. Yapılan analiz sonucu elde edilen bulgular Çizelge 12'de özetlenmiştir. 
Çizelge 12. Öğretmenlerin Hizmet Sürelerine Göre Ölçme ve Değerlendirme İlkelerine Dayalı Uygulamaları Gerçekleştirme Sıklıklarına Ait Cramer V Değerleri

\begin{tabular}{lllllllll}
\hline $\begin{array}{l}\text { Madde } \\
\text { No }\end{array}$ & $\begin{array}{l}\text { Cramer } \\
\text { V }\end{array}$ & $\mathbf{p}$ & $\begin{array}{l}\text { Madde } \\
\text { No }\end{array}$ & $\begin{array}{l}\text { Cramer } \\
\text { V }\end{array}$ & $\mathbf{p}$ & $\begin{array}{l}\text { Madde } \\
\text { No }\end{array}$ & $\begin{array}{l}\text { Cramer } \\
\text { V }\end{array}$ & $\mathbf{p}$ \\
\hline $\mathbf{1}$ &, 15 &, 07 & $\mathbf{1 1}$ &, 13 &, 12 & $\mathbf{2 1}$ &, 08 &, 39 \\
$\mathbf{2}$ &, 04 &, 77 & $\mathbf{1 2}$ &, 01 &, 98 & $\mathbf{2 2}$ &, 01 &, 97 \\
$\mathbf{3}$ &, 09 &, 36 & $\mathbf{1 3}$ &, 07 &, 54 & $\mathbf{2 3}$ &, 03 &, 89 \\
$\mathbf{4}$ &, 08 &, 44 & $\mathbf{1 4}$ &, 05 &, 68 & $\mathbf{2 4}$ &, 08 &, 46 \\
$\mathbf{5}$ &, 13 &, 10 & $\mathbf{1 5}$ &, 05 &, 67 & $\mathbf{2 5}$ &, 07 &, 75 \\
$\mathbf{6}$ &, 11 &, 22 & $\mathbf{1 6}$ &, 01 &, 96 & $\mathbf{2 6}$ &, 05 &, 74 \\
$\mathbf{7}$ &, 07 &, 49 & $\mathbf{1 7}$ &, 02 &, 93 & $\mathbf{2 7}$ &, 07 &, 49 \\
$\mathbf{8}$ &, 02 &, 90 & $\mathbf{1 8}$ &, 01 &, 98 & $\mathbf{2 8}$ &, 06 &, 64 \\
$\mathbf{9}$ &, 12 &, 18 & $\mathbf{1 9}$ &, 13 &, 13 & $\mathbf{2 9}$ &, 07 &, 54 \\
$\mathbf{1 0}$ &, 10 &, 25 & $\mathbf{2 0}$ &, 15 &, 07 & $\mathbf{3 0}$ &, 03 &, 83 \\
\hline
\end{tabular}

Çizelge 12 incelendiğinde, Cramer V değerlerinin istatistiksel bakımdan manidar olmadığ 1 görülmektedir. Buna göre, araştırma grubu içerisinde yer alan sınıf öğretmenlerinin, öğretmenlik mesleğindeki hizmet süreleri ile ölçme ve değerlendirme ilkelerine dayalı uygulamaları gerçekleştirme sıklıkları arasında manidar bir ilişki bulunmadığ saptanmıştır.

4) Sınıf öğretmenlerinin, ölçme ve değerlendirme ilkelerine dayalı uygulamaları eğitim öğretim etkinlikleri içinde gerçekleştirme sıklıkları ile mezun oldukları fakülte arasında manidar bir ilişki var mıdır?

$\mathrm{Bu}$ araştırma sorusunu yanıtlamak için, ilgili değişkenlere ilişskin Cramer V değerleri hesaplanmıştır. Yapılan istatistikler sonucu elde edilen bulgular Çizelge 13'te özetlenmiştir.

Çizelge 13. Öğretmenlerin Mezun Oldukları Fakülteye Göre Ölçme ve Değerlendirme İlkelerine Dayalı Uygulamaları Gerçekleştirme Sıklıklarına Ait Cramer V Değerleri

\begin{tabular}{lllllllll}
\hline $\begin{array}{l}\text { Madde } \\
\text { No }\end{array}$ & $\begin{array}{l}\text { Cramer } \\
\mathbf{V}\end{array}$ & $\mathbf{p}$ & $\begin{array}{l}\text { Madde } \\
\text { No }\end{array}$ & $\begin{array}{l}\text { Cramer } \\
\mathbf{V}\end{array}$ & $\mathbf{p}$ & $\begin{array}{l}\text { Madde } \\
\text { No }\end{array}$ & $\begin{array}{l}\text { Cramer } \\
\mathbf{V}\end{array}$ & $\mathbf{p}$ \\
\hline $\mathbf{1}$ &, 09 &, 36 & $\mathbf{1 1}$ &, 15 &, 06 & $\mathbf{2 1}$ &, 02 &, 92 \\
$\mathbf{2}$ &, 01 &, 98 & $\mathbf{1 2}$ &, 04 &, 78 & $\mathbf{2 2}$ &, 03 &, 90 \\
$\mathbf{3}$ &, 09 &, 34 & $\mathbf{1 3}$ &, 03 &, 89 & $\mathbf{2 3}$ &, 15 &, 06 \\
$\mathbf{4}$ &, 12 &, 18 & $\mathbf{1 4}$ &, 01 &, 97 & $\mathbf{2 4}$ &, 07 &, 51 \\
$\mathbf{5}$ &, 04 &, 75 & $\mathbf{1 5}$ &, 11 &, 19 & $\mathbf{2 5}$ &, 12 &, 28 \\
$\mathbf{6}$ &, 07 &, 52 & $\mathbf{1 6}$ &, 09 &, 34 & $\mathbf{2 6}$ &, 06 &, 57 \\
$\mathbf{7}$ &, 01 &, 98 & $\mathbf{1 7}$ &, 18 &, 06 & $\mathbf{2 7}$ &, 02 &, 90 \\
$\mathbf{8}$ &, 01 &, 99 & $\mathbf{1 8}$ &, 06 &, 64 & $\mathbf{2 8}$ &, 10 &, 29 \\
$\mathbf{9}$ &, 07 &, 55 & $\mathbf{1 9}$ &, 02 &, 95 & $\mathbf{2 9}$ &, 09 &, 38 \\
$\mathbf{1 0}$ &, 07 &, 55 & $\mathbf{2 0}$ &, 06 &, 62 & $\mathbf{3 0}$ &, 08 &, 47 \\
\hline
\end{tabular}


Çizelge 13 incelendiğinde, Cramer $\mathrm{V}$ değerlerinin oldukça düşük olduğu ve istatistiksel bakımdan manidar olmadığı görülmektedir. Buna göre, araştırma grubu içerisinde yer alan sınıf öğretmenlerinin eğitim fakültesi mezunu olup olmamaları ile ankette yer alan ölçme ve değerlendirme uygulamalarını gerçekleştirme sıklıkları arasında manidar bir ilişki bulunmadığı saptanmıştır.

5) Sınıf öğretmenlerinin, ölçme ve değerlendirme uygulamalarına ilkelerine dayalı uygulamaları eğitim öğretim etkinlikleri içinde gerçekleştirme sıklıkları ile sahip oldukları sınıf mevcudu arasında manidar bir ilişki var mıdır?

$\mathrm{Bu}$ araştırma sorusunu yanıtlamak için, ilgili değişkenlere ilişkin Cramer V değerleri hesaplanmıştır. Yapılan istatistikler sonucu elde edilen bulgular Çizelge 14'te özetlenmiştir.

Çizelge 14. Öğretmenlerin Sahip Oldukları Sinıf Mevcuduna Göre Ölçme ve Değerlendirme İlkelerine Dayalı Uygulamaları Gerçekleştirme Sıklıklarına Ait Cramer V Değerleri

\begin{tabular}{lllllllll}
\hline $\begin{array}{l}\text { Madde } \\
\text { No }\end{array}$ & $\begin{array}{l}\text { Cramer } \\
\mathbf{V}\end{array}$ & $\mathbf{p}$ & $\begin{array}{l}\text { Madde } \\
\text { No }\end{array}$ & $\begin{array}{l}\text { Cramer } \\
\mathbf{V}\end{array}$ & $\mathbf{p}$ & $\begin{array}{l}\text { Madde } \\
\text { No }\end{array}$ & $\begin{array}{l}\text { Cramer } \\
\mathbf{V}\end{array}$ & $\mathbf{p}$ \\
\hline $\mathbf{1}$ &, 14 &, 27 & $\mathbf{1 1}$ &, 12 &, 46 & $\mathbf{2 1}$ &, 16 &, 18 \\
$\mathbf{2}$ &, 11 &, 52 & $\mathbf{1 2}$ &, 11 &, 52 & $\mathbf{2 2}$ &, 11 &, 52 \\
$\mathbf{3}$ &, 09 &, 75 & $\mathbf{1 3}$ &, 12 &, 48 & $\mathbf{2 3}$ &, 13 &, 36 \\
$\mathbf{4}$ &, 22 &, 22 & $\mathbf{1 4}$ &, 09 &, 69 & $\mathbf{2 4}$ &, 10 &, 61 \\
$\mathbf{5}$ &, 11 &, 52 & $\mathbf{1 5}$ &, 16 &, 16 & $\mathbf{2 5}$ &, 11 &, 78 \\
$\mathbf{6}$ &, 05 &, 95 & $\mathbf{1 6}$ &, 10 &, 62 & $\mathbf{2 6}$ &, 10 &, 66 \\
$\mathbf{7}$ &, 15 &, 21 & $\mathbf{1 7}$ &, 15 &, 21 & $\mathbf{2 7}$ &, 12 &, 42 \\
$\mathbf{8}$ &, 10 &, 62 & $\mathbf{1 8}$ &, 07 &, 88 & $\mathbf{2 8}$ &, 18 &, 09 \\
$\mathbf{9}$ &, 13 &, 35 & $\mathbf{1 9}$ &, 07 &, 84 & $\mathbf{2 9}$ &, 05 &, 95 \\
$\mathbf{1 0}$ &, 13 &, 34 & $\mathbf{2 0}$ &, 13 &, 39 & $\mathbf{3 0}$ &, 16 &, 16 \\
\hline
\end{tabular}

Çizelge 14 incelendiğinde, Cramer $\mathrm{V}$ değerlerinin oldukça düşük olduğu ve istatistiksel bakımdan manidar olmadığı görülmektedir. Buna göre, araştırma grubu içerisinde yer alan sınıf öğretmenlerinin sahip oldukları sınıf mevcuduna göre ölçme ve değerlendirme ilkelerine dayalı uygulamaları gerçekleştirme sıklıkları değişmemektedir. 


\section{TARTIŞMA VE SONUÇ}

$\mathrm{Bu}$ araştırmanın bulguları çeşitli yerli ve uluslar arası alan yazın kapsamında değerlendirildiğinde genel olarak desteklenme eğilimindedir. Kazanımları esas alarak değerlendirme yapmak, ölçme ve değerlendirme uygulamalarını planlamak öğretmenlerin yaklaşık yarısı tarafından gerçekleştirilen uygulamalardır. Değerlendirme etkinliklerini planlamak ve dersin amaçlarını ögrencilere yazılı olarak bildirmek, öğrencilerin güçlü ve geliştirilmesi gereken yönlerini ortaya çıkarıcı değerlendirmeler yapmak, öğrencilere akademik gelişimleri hakkında geribildirim vermek, akran değerlendirmeleri yaptırmak öğretmenlerin çoğunluğu tarafindan yeterince gerçekleştirilmeyen uygulamalardır. Bunlara ek olarak, öz değerlendirmeler yaptırmak, küçük-kısa değerlendirme etkinlikleri yapmak, sözlü becerileri değerlendirmek, öğrencilere yeni bir konuya başlarken neler öğrenmeyi beklediklerini sormak ve anekdot kayıtları tutmak öğretmenlerin çoğunluğu tarafindan yeterince gerçekleştirilmeyen etkinliklerdir. Öğretmenlerin söz konusu uygulamaları gerçekleştirmeme nedenleri bu konudaki donanımlarının eksikliğine bağlanabilir. Nitekim, bazı araştırma bulguları da ilk ve ortaöğretim öğretmenlerinin ölçme ve değerlendirmenin temel kavramları tanıma düzeyleri ve bunları uygulamaları konusunda yeterli olmadıklarını göstermiştir (Ulutaş, 2003; Güneş, 2007). Sınav sorularını, öğrenciyi üst düzey düşünmeye sevk edecek düzeyde ve gündelik yaşam durumlarına dayalı olarak hazırlamak öğretmenlerin az oranda gerçekleştirdikleri uygulamalardır. Bu bulgu ile TIMSS, PISA gibi uluslar arası çapta uygulanan Matematik ve Fen Bilgisi sinavlarında Türk öğrencilerinin üst düzey düşünme becerilerini kullanmalarını gerektiren sorularda neden başarısız oldukları sorusuna kısmen yanıt verebilir. Türk öğrencileri bu ölçme uygulamalarında ortalama puanın altında ve genelliklede alt yeterlik düzeylerinde kalmışlar (MEB, 2007; Mullis ve diğerleri, 2008a; Mullis ve diğerleri, 2008b). Öğrencilerin sınıf içi değerlendirme uygulamalarında üst düzey düşünme becerilerini kullanmalarını gerektirecek durumlarla karşılaşmamaları onları bu becerilerin ölçüldüğü durum belirleme çalışmalarında dezavantajlı kılmış olabilir.

Değerlendirmeyi öğretim sürecinde telafi edilmesi gereken alanları ve becerileri saptamak için kullanmak, öğrencilerin başarısızlık nedenlerini ortaya koyacak gözlemler yapmak, velilere geribildirimlerde bulunmak, ürün seçki dosyasını başarıyı değerlendirmede kullanmak kadın öğretmenlerin daha sık gerçekleştirdikleri uygulamalardır. Ataman (2007) tarafından yapılan araştırmada da ölçme ve değerlendirme uygulamalarında kadın öğretmenlerin daha başarılı olduğu saptanmıştır. 
Araştırmada, puanlanmış sınav kağıtlarını öğrencilere dağıtarak, öğrencilerin eksik ve güçlü yönlerini görmelerini sağlamak, gibi etkinliklerin sınıf öğretmenlerince, az oranda uygulandığı sonucuna ulaşılmıştır. Aralarında Türkiye'nin de yer aldı ̆̆ 1 ülkelerin öğrencilerinin yansıra öğretmenlere de öğretim ve değerlendirme etkinliklerini yoklayan anketlerin uygulandığı TIMSS uygulamasının bulguları ile tutarlık göstermektedir (TIMSS, 1999). Buna göre Türk öğretmenler ölçme sonuçları çoğu kez "not vermek" amacı ile kullanırlarken, öğrenci ve aileye geri bildirimde bulunmak amacıyla nadiren kullandıklarını belirtmişlerdir.

$\mathrm{Bu}$ araştırmada öğretmenlerin, klasik değerlendirme yaklaşımlarını (çoktan seçmeli, kısa cevap, eşleştirme ve doğru-yanlış türündeki sorularla yazılı sınav yapma) çok sık uyguladıkları saptanmıştır. Bu bulgu, Güven (2001) ve Çakan (2004)'nın elde ettikleri bulgularla paralellik göstermektedir.

Dereceli puanlama anahtarı ile değerlendirmeler yapmak, tutum ölçeklerinden yararlanmak, öğrencilere, gösteri veya sergileme türü etkinlikleri gerçekleştirme olanağ1 sağlamak, performans değerlendirmeleri yapmak, öğrencilerle küçük gruplar halinde görüşmeler yapmak, tartışma grupları oluşturmak ve proje çalışmaları yaptırmak yeterince gerçekleştirilemeyen uygulamalardır. Tabak (2007) ve Gelbal ve Kelecioğlu (2007) tarafindan yapılan araştırmalarda öğretmenlerin öğrenci merkezli ölçme değerlendirme yaklaşımlarını yeterince kullanamadıkları saptanmıştır. Kanatlı (2008) ve Algan (2008)'ın bulguları, sınıf öğretmenlerinin öğrenci merkezli ölçme ve değerlendirme tekniklerini kullanma konusunda çeşitli zorluklar yaşadıkları ve bu zorlukların başında zaman darlığı, kaynak yetersizliği ve sınıfların kalabalık olması nedeniyle öğrenci merkezli ölçme ve değerlendirme araçlarını uygulayamadıklarını göstermiştir. Buna göre bu gerekçeler öğretmenlerin yukarıda sözü edilen uygulamaları gerçekleştirememe nedenleri arasında sayılabilir. Ancak bu araştırmada, sınıf büyüklüğü ile ölçme etkinliklerinin yapılma sıklığg ile bir ilişki bulunmamıştır.

Araştırma bulguları genel olarak incelendiğinde, öğretmenlerin ölçme ve değerlendirme uygulamalarını yeterince gerçekleştiremedikleri saptanmıştır. $\mathrm{Bu}$ araştırmaların bulgularına göre, bu durumun, mezun olunan fakülte, sınıf mevcudu veya meslekteki hizmet süresi gibi değişkenler ile ilintili olmadığı bulunmuştur. Asıl nedenin, öğretmenlerin lisans eğitimleri sırasında bu alanda temel bilgi ve becerileri kazanmayı sağlayıcı ders ve uygulamaların yeterli olmaması olasıdır. Ayrıca yenilenen ilköğretim programlarına ilişkin öğretmenlere yol gösterici olması için hazırlanan öğretmen kılavuz kitaplarındaki kazanımlar ile önerilen etkinlikler arasında 
önemli ölçüde uyumsuzluk olduğu, kazanım ifadelerinin belirsizlik taşıdığı ve ölçülebilir nitelikte olmadığı saptanmıştır (Berberoğlu, Arıkan, Demirtaşl1, İş Güzel ve Özgen Tuncer, 2009). Bu durum da öğretmenlerin yenilenen ilköğretim programlarının gerektirdiği ölçme araç ve yaklaşımlarını doğru yerinde kullanmalarını ve doğru uygulamalarını zorlaştırmış olabilir. Araştırma bulguları bu ve buna benzer gruplarla sınırlıdır. Bu nedenle araştırmanın daha geniş örneklemlerde tekrarlanılması sonuçların genellenmesi açısından önem taşımaktadır. Bu konuda bundan sonraki yapılacak araştırmalarda, farklı öğretim kademelerinde, branşlarda ve okul türlerinde çalışan öğretmenlerin ölçme ve değerlendirme uygulamalarını gerçekleştirme durumları karşılaştırılabilir. Bu tür çalışmalar daha küçük gruplarda derinlemesine bilgi verecek nitel araştırmalarla da desteklenebilir.

Sonuç olarak bu ve diğer araştırmaların da ortaya koyduğu üzere öğretmenlerin öğrenci başarısını ölçme ve izleme ile ilgili temel yeterliklere sahip olması beklenir. Öğretmenlerin ölçme ve değerlendirme alanındaki yeterlikleri verimli bir eğitim ortamının oluşmasında çok önemli bir role sahiptir. Ancak bu belirleme, öğretmenin bir ölçme ve değerlendirme uzmanı gibi çalışacağı anlamına gelmemektedir. Öğretmenlerin bu alandaki yeterliklerinin, özellikle üst düzey düşünme becerilerini ölçecek soru yazma, değerlendirme sürecinde farklı ölçme araç ve yaklaşımları bir arada kullanma, ölçme sonuçlarının sadece not vermek amaçlı değil öğrenmeleri geliştirme amaçlı olarak kullanımı konusunda geliştirilmesi önceliklidir. Bu bağlamda öğretmenin sınıf içinde yaptığı ölçmelerin standart ölçme ve değerlendirme sistemleriyle de desteklenmesi gerekir.

\section{KAYNAKLAR}

Aiken, L.R. (1997). Questionnaires \& Inventories: Surveying Options and Assessing Personality. John Wiley \& Sons: NY

Algan, S. (2008). "Illkögretim 6. ve 7. Sintf Sosyal Bilgiler Dersi Öğretim Programının Ölçme ve Değerlendirme Öğesinin Ögretmen Görüşleri Açısından Incelenmesi." Yayımlanmamış yüksek lisans tezi. Çukurova Üniversitesi, Sosyal Bilimler Enstitüsü, Adana.

Ataman, M. (2007). "Benzeşen ve Ayrışan Yönleriyle 1998 ve 2004 İlkögretim Sosyal Bilgiler "Öğretim Programlarında (4.-5. Sinıflar) Ölçme ve Değerlendirme Yöntem ve Teknikleri ve Bunlara İlişkin Öğretmen Görüşleri." Yayımlanmamış. yüksek lisans tezi. Marmara Üniversitesi, Eğitim Bilimleri Enstitüsü, İstanbul.

Aydın, A. (2001). Ĕgitim Fakültesi Mezunu Olan ve Olmayan Öğretmenlerin Ölçme ve Değerlendirme Yeterliklerinin Karşılaştırllmasına Yönelik Bir 
Çalışma. Yayımlanmamış yüksek lisans tezi. Ankara Üniversitesi, Eğitim Bilimleri Enstitüsü, Ankara.

Aydın, F. (2005). Öğretmenlerin Alternatif Ölçme Değerlendirme Konusundaki Düşünceleri ve Uygulamaları. 14. Ulusal Eğitim Bilimleri Kongresi'nde sunulmuş bildiri, Denizli.

Aykaç, N. ve Başar, E. (2005). İlköğretim Sosyal Bilgiler Dersi Eğitim Programının Değerlendirilmesi. Ĕgitimde Yeni Yansımalar VIII, Yeni İlkögretim Programlarını Değerlendirme Sempozyumu, (ss. 343-361). Ankara: Sim Matbaasi.

Berberoğlu, G., Arıkan, S., Demirtaşl1, N., İş Güzel, Ç. ve Özgen Tuncer, Ç. (2009). Illkögrretim 1.-5. Sinıflar arasindaki ögretim programlarinin kapsam ve ögrenme çıktıları açısından değerlendirilmesi. Cito Eğitim: Kuram ve Uygulama. Ocak-Şubat (1), 9-48.

Collins, A. (2005). İlköğretim Türkçe Programları Pilot Uygulama Değerlendirmesi. Ĕgitimde Yeni Yansımalar VIII, Yeni İlköğretim Programlarını Değerlendirme Sempozyumu, (ss. 343-361). Ankara: Sim Matbaasi.

Coşkun, E. (2005). İlköğretim Dördüncü ve Beşinci Sınıf Öğretmen ve Öğrencilerinin Yeni Türkçe Dersi Öğretim Programıyla İlgili Görüşleri Üzerine Nitel Bir Araştırma. Kuram ve Uygulamada Eğitim Bilimleri Dergisi, 5 (2), 421-476.

Çakan, M. (2004). Öğretmenlerin Ölçme ve Değerlendirme Uygulamaları ve Yeterlik Düzeyleri: İlk ve Ortaöğretim. Ankara Üniversitesi Ĕgitim Bilimleri Fakültesi Dergisi, 37 (2), 99-114.

Erdoğan, M. (2005). Yeni Geliştirilen Beşinci Sınıf Fen ve Teknoloji Dersi Müfredatı: Pilot Uygulama Yansımaları. Eğitimde Yeni Yansımalar VIII, Yeni İlköğretim Programların Değerlendirme Sempozyumu, (ss: 299-310). Ankara: Sim Matbaas1.

Gelbal, S. ve Kelecioğlu H. (2007). Öğretmenlerin Ölçme ve Değerlendirme Hakkındaki Yeterlik Algıları ve Karşılaştıkları Sorunlar. Hacettepe Üniversitesi Eğitim Fakültesi Dergisi, 33, 135-145.

Gözütok, D., Ergün, E.Ö. ve Karacaoğlu, C. Ö., (2005). İlköğretim Programlarının Öğretmen Yeterlikleri Açısından Değerlendirilmesi. Eğitimde Yeni Yansımalar VIII, Yeni İlköğretim Programlarını Değerlendirme Sempozyumu, (ss:17-40). Ankara: Sim Matbaas1.

Gullickson, A. R. (1984). Teacher Perspectives of Their Instructional Use of Tests. Journal of Educational Research, 77 (4), 244-248.

Gümüş, B. (1981). "Ölçme ve Değerlendirme Dersinin Öğretmenlerin Ögrenci Başarısını Değerlendirme Davranışına Katkısı." Yayımlanmamış yüksek lisans tezi. Ankara Üniversitesi, Eğitim Bilimleri Enstitüsü, Ankara.

Güneş, A. (2007). "Sinıf Öğretmenlerinin Kendi Algılarına Göre Ölçme ve Değerlendirme Yeterlikleri." Yayımlanmamış yüksek lisans tezi. Marmara Üniversitesi, Eğitim Bilimleri Enstitüsü, İstanbul.

Güven, S. (2001). Sinıf Ögretmenlerinin Ölçme ve Değerlendirmede Kullandıkları Yöntem ve Tekniklerin Belirlenmesi. 10. Ulusal Eğitim 
Bilimleri Kongresi, (ss: 413-423). Bolu: Abant İzzet Baysal Üniversitesi Basımevi.

Kanatlı, F. (2008). "Alternatif Ölçme Değerlendirme Teknikleri Konusunda Sinıf Ögretmenlerinin Görüslerinin Değerlendirilmesi." Yayımlanmamış yüksek lisans tezi. Mustafa Kemal Üniversitesi, Sosyal Bilimler Enstitüsü, Hatay.

Kaynak, S. (2000). "Ortaögrretimdeki Branş Öğretmenlerinin Öğrenci Başarısını Ölçme ve Değerlendirme ile Illgili Görüşlerinin Değerlendirilmesi." Yayımlanmamış yüksek lisans tezi. Mustafa Kemal Üniversitesi, Sosyal Bilimler Enstitüsü, Hatay.

Küçükahmet, L. (2005). 2004 Hayat Bilgisi Programının Değerlendirilmesi. Ĕ̈itimde Yeni Yansimalar

VIII, Yeni İlköğretim Programlarını Değerlendirme Sempozyumu, (ss: 373381). Ankara: Sim Matbaas1.

MEB. (2007). PISA 2006 Uluslararası Öğrenci değerlendirme Programı Ulusal Ön Rapor.

Merter, F. (2005). Hayat Bilgisi ve Sosyal Bilgiler Dersi Programının Eğitim Sosyolojisi Bakış Açısından Olumlu ve Olumsuz Eleştirisi, Eğitimde Yeni Yansımalar VIII, Yeni İlköğretim Programlarını Değerlendirme Sempozyumu, (ss. 430-439). Ankara: Sim Matbaas1.

Mertler, C. A. (2000). Assessing Student Performance: A Descriptive Study Of The Classroom Assessment Practices Of Ohio Teachers. Education, 120 (2), 285-297.

Mullis, I..S., Martin, M.O., Foy, P., Olson, J.F., Preuschoff, C., Erberber, E., Arora, A., and Galia, J. (2008a). TIMSS 2007 International Mathematics Report: Findings from IEA's Trends in International Mathematics and Science Study at the Fourth and Eighth Grades.Chestnut Hill, MA: TIMSS \& PIRLS International Study Center, Boston College.

Mullis, I..S., Martin, M.O., Foy, P., Olson, J.F., Erberber, E., Preuschoff, C. and Galia, J. (2008b). TIMSS 2007 International Science Report: Findings from IEA's Trends in InternationalMathematics and Science Study at the Fourth and Eighth Grades. Chestnut Hill, MA: TIMSS \& PIRLS International Study Center, Boston College.

Özçelik, D. A. (1992). Ölçme ve Değerlendirme. Ankara: ÖSYM Yayınları.

Özdaş, A., Tanışlı, D., Köse, N. Y. ve Kılıç, Ç. (2005). Yeni İlköğretim Matematik Dersi (1.-5. Sinıflar) Öğretim Programının Öğretmen Görüşlerine Dayalı Olarak Değerlendirilmesi, Ĕgitimde Yeni Yansımalar VIII, Yeni İlköğretim Programlarını Değerlendirme Sempozyumu (ss: 239-255). Ankara: Sim Matbaas1.

Özdamar, K. (2004). Paket Programlar ile İstatistiksel Veri Analizi (5. bask1). Eskişehir: Kaan Kitabevi.

Özoğlu, S. Ç. ve Koç, N. (1995). Çağdaş Üniversitede Öğrencinin Akademik Başarısının Ölçülmesi ve Değerlendirilmesi. Ankara: Ankara Üniversitesi Basımevi. 
Sever, S. (2005). 2004 Öğretim Programında Türkçe Öğretimi Anlayış1, Eğitimde Yeni Yansimalar VIII, Yeni İlkögretim Programlarını Değerlendirme Sempozyumu, (ss:177-192). Ankara: Sim Matbaasi.

Shaughnessy, J.J. and Zechmeister,E.B. (1997). Research Methods in Psychology. McGrawHill: Singapore.

Stiggins, R. J. (2002). Assessment crisis. The absence of assessment for learning. Phi Delta Kappan, 83 (10), 758-765.

Stiggins, R. J. and Chappuis, S. (2005) Using Student Involved Classroom Assessment to Close Achievement Gaps. Theory Into Practice, 44 (1), $11-18$

Tabak, R. (2007). “Illköğretim 5. Sinlf Fen ve Teknoloji Ders Programinın Ögrenme -Ögretme ve Ölçme Değerlendirme Yaklaşımları Kapsamında İncelenmesi (Muğla İli Örneği)." Yayımlanmamış yüksek lisans tezi. Muğla Üniversitesi, Sosyal Bilimler Enstitüsü, Muğla.

TIMSS (1999). Mathematics Teacher Background with Mathematics Achievement, Main Survey, Third International Mathematics and Science Study. http://timss.bc.edu/timss1999i/questionnaires.html adresinden 12/05/2009 tarihinde erişildi.

TIMSS (2007a). International Mathematics Report. http://timss.bc.edu/timss2007/mathreport.html adresinden 04/05/2009 tarihinde erişildi.

TIMSS (2007b). International Science Report. http://timss.bc.edu/timss2007/sciencereport.html adresinden 04/05/2009 tarihinde erişildi.

Ulutaş, S. (2003). "Genel Liselerdeki Öğretmenlerin Ölçme ve Değerlendirme Alanındaki Yeterlikleri Ile Ölçme ve Değerlendirme İlkelerini Uygulama Düzeylerinin Araştırllması." Yayımlanmamış yüksek lisans tezi. Ankara Üniversitesi, Eğitim Bilimleri Enstitüsü, Ankara.

Yaşar, Ş., Gültekin, M., Türkan, B., Yıldız, N. ve Girmen, P. (2005). Yeni İlköğretim Programlarının Uygulanmasına İlişkin Sınıf Öğretmenlerinin Hazır Bulunuşluk Düzeylerinin ve Eğitim Gereksinimlerinin Belirlenmesi, Ĕgitimde Yeni Yansimalar VIII, Yeni İlköğretim Programlarını Değerlendirme Sempozyumu, (ss: 51-63). Ankara: Sim Matbaas1.

Zhang, Z. and Burry-Stock, J. A. (2003). Classroom Assessment Practices And Teachers' Self-Perceived Assessment Skills. Applied Measurement in Education, 16 (4), 323-342. 
